\title{
Personal Financial Coaching, Part I: Basics The Public Needs To Know
}

Jason T. White, Northwest Missouri State University, USA

J. Patrick McLaughlin, Northwest Missouri State University, USA

\begin{abstract}
In the course of our university service to the community in outreach activities, we have gravitated toward providing occasional group sessions in personal financial planning. On the surface, the content of these financial coaching events may appear elementary to the casual observer. But to the contrary, we have found that personal financial planning is a sorely needed skill set for many in our region. Our typical session touches on the basic elements of family budgeting, retirement planning, goal setting and behavior modification. Those contemplating establishment of a similar program of study may benefit from our field experience.
\end{abstract}

Keywords: Personal finance; Budgeting; Emergency fund; Household debt; Family; Money; Retirement; Savings

\section{INTRODUCTION}

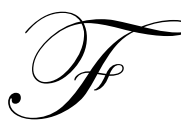

ew can legitimately question the importance of personal financial knowledge for individuals and families. From the college student beginning his working life with a mountain of student loan and credit card debt, to the family struggling to save for housing, education and retirement, to the elderly concerned about outliving income or being inadequately insured against risk, short and long run financial concerns face us all. "Because financial literacy has been shown to correlate with good financial decision making, policymakers promote educational programs to improve individuals' financial acumen." ${ }^{1}$ While our work is the field of personal financial coaching has not been mandated by our institution, it is certainly endorsed as a beneficial public service.

Personal financial coaching encompasses two key elements: planning and education. Absent a prudent financial plan, financial education cannot be put to good use; similarly, inadequate financial education is a substantial impediment to proper planning. ${ }^{2}$ "Although many employers offer financial education to their employees, several studies indicate that retirement savings plans are not achieving the primary goals for which they are designed." Additionally, "(a)t the state level, a small but growing number of states are encouraging or requiring teachers to integrate personal finance concepts into core subjects..."4

While we are unable to change the rules and regulatory landscape of personal finance, personal financial coaching helps individuals navigate this terrain by increasing both the knowledge base and planning propensity of participants in our ad hoc programs.

\section{PERSONAL FINANCIAL COACHING - CRITICAL STEPS}

1. Establish the Family Budget

2. Establish an Emergency Fund

3. Pay-off Debts from Highest Interest Rate to Lowest

a. If interest rates are substantially equally, pay-off balances from smallest to largest

4. $\quad$ Fully Fund Retirement Savings Plans to Maximize Employer Match 401(k)s and 403(b)s

5. Fully Fund Other Retirement Savings Plans (IRAs and Roth IRAs)

6. Conduct a Full Insurance Review

7. Have a Will, Durable Power of Attorney and Health Care Directive prepared 
8. $\quad$ Begin and Fund Education Savings Plan(s)

9. Review/Start Estate Planning to help eliminate distribution and tax issues

10. Pay Extra Principal Payments on Mortgage Debt to reduce interest costs

11. Establish a Charitable Giving Plan

12. Build safeguards to protect your plan for the future

In this paper, we will only examine the critical steps of the family budget and retirement savings. (Future research will be focused on the other critical steps set forth above.

\section{THE FAMILY BUDGET}

In our financial counseling and law experience, this mundane personal financial planning task has likely led to more arguments, hurt feelings, deception and divorces than most any other marital issue this side of infidelity. Money is both a personal and impersonal commodity. ${ }^{5}$ Loans are predicated on the personal trustworthiness of an individual to repay, while money is also impersonal when viewed as a commodity that can be transferred from savers to debtors via some financial intermediary. This free flow of capital lubricates the gears of the capitalist system in a generally positive way, though individual financial outcomes can be less desirable.

Personal financial distress, and the looming threat of bankruptcy for families suffering budgeting hardship, cries out for establishment of a written family budget itemizing all sources of family income and outgo on a periodic basis. Rotfeld (2008) confirms that some critical financial mistakes can be mitigated with greater financial literacy. ${ }^{6}$ In our previous presentations on this topic, we recommend a simple monthly budgeting process, categorizing income flows and spending in two separate columns.

On the left hand side of the page, families should list each source and amount of annual net (take-home) pay, divided by twelve. We have found it problematic in budgeting for families to list gross (pre-tax) income here, as it gives the illusion that a larger pot of money available for expenses exists than is actually the case.

On the income side of the ledger, one of the big problems in budgeting is a widespread lack on income transparency in modern society. That is, people do not have ready or reliable access to information on what their coworker, peers or neighbors are earning, and the subject of personal earnings is a taboo topic of discussion in most social circles. ${ }^{7}$ Thus, a common personal financial mistake is attempting to compare one's household budget to that of a neighbor's in the absence of truly reliable information. The old cliché "Keeping up with the Joneses" risks overspending given what the household intake can sustain.

The next logical step is determining the expenditure budget. Expenses like housing, utilities, food and other necessities should be annualized and then also divided by twelve. ${ }^{8}$ Nonrecurring discretionary expenditure items should be treated in the same fashion. Some with a philanthropic bent suggest a simple rule of thumb with regard to the family budget: give 10-percent; save 10-percent; and live happily and within your means on the remaining 80-percent. These are after-tax recommendations, of course.

Like a corporate profit and loss statement, the family budget nets are derived from monthly income versus expenditures with the resulting balance being either positive or negative balance. A positive bottom line allows for additional personal savings opportunities through a variety of investment vehicles. It is no secret to most that the personal savings rate in the United States is on the decline, although due to measurement errors this decline may not be as large a cause for concern as it appears on the surface. ${ }^{9}$ However, to meet future needs and objectives "everybody knows" that most every household needs to save more than they currently do.

In our presentation, we explain a recurring budget shortfall or monthly loss is akin to negative retained earnings at the level of a business unit. Often, families are reluctant to deal with negative cash flow issues and personal negative retained earnings pile up. This may be due to the declining stigma of personal bankruptcy among middle class families facing financial distress. ${ }^{10}$ However, households where both adult partners make joint decisions with regard to spending tend to be more satisfied with family life. ${ }^{11}$ We have found in such situations that personal budgeting outcomes are improved, but there appears to be no universal confirmation of this observation. 
American households are awash in debt thanks to accumulated negative personal retained earnings. This fact has precipitated the macroeconomic financial and credit crisis that is afflicting global markets. For many, personal reliance on debt instruments begins early in life, often among traditional college age students. The main culprits, student loans and credit cards, put many young people into a financial hole before their careers even begin. In fact, in a survey of 149 first-year business students, Marriott reports a mean score of 34-percent regarding personal financial awareness. ${ }^{12}$ It appears clear that household financial problems often begin before the adult household is even formed and before young adults are equipped with the basic knowledge of personal financial management.

Further, from a general welfare standpoint, Adams and Moore (2007) have shown that high-risk credit behavior is associated with other high-risk activities among youth like drunken-driving, drug use, and unprotected sex. ${ }^{13}$ While debt is not universally evil, as some pop-culture financial commentator's claim, it appears likely that reduced reliance on consumer debt may also have ancillary societal benefits in other areas.

One example of this is the observation that better educated and higher net worth elderly individuals, age 70 or older, tend to be better protected from common cognitive impairment diseases like Alzheimer's and dementia. ${ }^{14}$

With proper coaching, the family budget can be balanced, or a plan to correct imbalances can be put into place. Once this is accomplished, focus can shift to the main long-term goal for most individual savings programs, a comfortable retirement.

\section{RETIREMENT}

Among the people we have worked with in group financial planning sessions, the long-term goal of a comfortable retirement seems to be of universal concern. However, Duffy reports that specific "goal setting is the most often overlooked component of financial education programs..." 15 Most have some idea of the activities they would like to pursue in their golden years such as travel, leisure, time with family or charity work are ones often cited. An important question for many families is whether they have undergone proper financial planning to help ensure these goals become reality.

Stawski, Hershey and Jacobs-Lawson (2007) studied how retirement goal setting predicted personal financial planning practice, specifically with regard to savings habits. ${ }^{16}$ The authors found in their survey of 100 working adults that retirement goal clarity led to improved personal financial planning practices and predicted savings tendencies. As such, we have found it useful to challenge individuals to set personal retirement goals as a first step toward establishing healthy savings and investment behaviors through personal budgeting.

During the accumulation phase, as worker savings build retirement balances, we coach our seminar participants to set aside 10-to-15-percent of gross wages in tax deferred retirement accounts, most commonly in a 401(k), 403(b) and/or a (Roth) IRA. Generally speaking, Americans have not mastered the discipline of personal saving. In fact, Guidolin (2007) observes that the personal saving rate has been declining in recent years and is cause for concern. ${ }^{17}$ Especially if you are trying to reach your personal retirement goals.

Another interesting result came from a study of 795 higher education employees, Dulebohn (2007) found that financial literacy and investment knowledge had a direct effect on risk tolerance and behaviors. ${ }^{18}$ A basic fundamental axiom in retirement savings deals with age-adjusted risk tolerance. As one advances in age, investment risk-taking strategies should be reduced as the time to absorb significant return deviations is lessened. All too often, we have observed older, beginning-retirement-savers to take the opposite approach to risk. With their intended retirement date rapidly approaching, some discover themselves a good monetary distance away from their desired "number." As a result, these older savers take on more risk rather than less in hopes of making up their lifetime savings shortfall with higher returns. This is a poor tradeoff often resulting in severe financial disappointment.

Recent advances in financial products, such as the target date retirement mutual fund, have simplified appropriate age-risk investing practices. Unfortunately, too many defined-contribution retirement plans still do not include these funds choices as options for participants. 
Age and income appear to be the two most important explanatory variables related to retirement savings. ${ }^{19}$ As workers age, retirement looms larger as its commencement becomes more apparent. The cavalier attitude of many young people toward retirement planning begins to dissipate, and healthier savings practices start to take hold. However, a major risk is that one will come to recognize pending retirement far too late in their working lives because of a combination of lack of personal financial knowledge and a lack of savings discipline.

Of course, it should not be too surprising to learn that those with higher incomes have an easier time adjusting the family budget to begin building a retirement "nest egg." We have found that nearly all families we have consulted with recognize retirement as a paramount savings goal, but those with higher earnings obviously, at least in most cases, tend to have an easier time in adjusting spending habits to meet this challenge.

To generalize, workers on the lower end of the wage scale have more significant challenges to retirement savings than their higher earning counterparts. In a study of 300 lower-wage workers it was found that greater financial literacy was a significant predictor of retirement savings. ${ }^{20}$ Consequently, we coach that even relatively low wages are not an impenetrable impediment to saving for an adequate retirement. Additionally, Davis (2007), citing a study by the Fawcett Society, comments "(a)nyone in low-paid or part-time work, or who has taken time out of the workplace to have a family is at risk..." ${ }^{21}$ There are no easy shortcuts. Careful planning and systematic contributions to retirement account(s) are critical success factors to old-age income security.

Among the elderly, women can also face very unique problems. ${ }^{22}$ Death of their spouse, or a divorce in later life, can leave women who have been less attune to the workings of the family budget in a difficult spot. In our work, intelligence or financial acumen are not overriding problems, rather shock, fear and lack of budgeting experience can make the transition to planning as a single person quite difficult. Some become overwhelmed by the new responsibilities thrust at them, and unfortunately this can lead to mistakes, especially when dealing with financial planners who may not have their clients' best interests at heart.

Wealth reduction often occurs more quickly in the beginning years of the retirement life cycle. For example, during the first five years after an individual or couple retires spending is often higher, as retirees travel or pursue other leisure activities while still healthy. ${ }^{23}$ Personal financial coaching is critical at this juncture in life. If retirees spend their wealth too quickly in the early years of retirement, their risk of outliving their income rises substantially.

We advise a 4.5-percent annual withdrawal rate during retirement. Using a consumer price inflation target of 3.2-percent per annum, this implies the need for a 7.7-percent average annual return on invested retirement savings, which has been historically achievable with a portfolio allocation of 60-percent fixed income investments and 40-percent equities. Risk adverse retirees may wish to reduce their annual withdrawal rate to 4-percent, while those with higher risk tolerance may increase that to as high as 5-percent. In most all cases, we emphasize in our presentations that equity exposure is still needed in retirement as a hedge against inflation.

\section{CONCLUSION}

At Northwest Missouri State University, personal financial coaching has become an increasingly popular activity in our community service work. We have illustrated in this paper the importance of personal financial education and goal setting, regardless of age or income constraints. We have enumerated the critical steps of our personal financial coaching program and discussed both the family budget and retirement as an overview of two essential pieces of the much larger puzzle. In upcoming research, we plan to more closely examine other critical steps in the personal financial coaching process in hopes of better educating our community on other critical issues, essential to protecting their personal wealth and achieving their financial goals.

\section{AUTHOR INFORMATION}

Dr. Jason T. White, Assistant Professor in the Department of Accounting, Economics and Finance, has taught Economics, Finance and Entrepreneurship courses at Northwest Missouri State University since 1999. He is a licensed Registered Investment Advisor in the State of Missouri and a private financial consultant. He received his 
Ph.D. in Economics from the University of Missouri; an MBA from Rockhurst University; and a BS from Northwest. Dr. White has earned research and teaching awards sponsored at the international, national, regional and institutional level.

Dr. J. Patrick McLaughlin, Professor in the Department of Accounting, Economics and Finance, has taught Law and Insurance courses at Northwest Missouri State University since 1978. He is a practicing attorney, Municipal Judge and Prosecuting Attorney. He received his J.D. degree from the University of Missouri at Kansas City and his B.S.B.A. degree from Central Missouri State University. Dr. McLaughlin has also received numerous Best Paper Awards and Excellence in Teaching Awards, including the Governor's Award, multiple Dean's Awards and the Northwest Alumni Outstanding Educator Award.

\title{
END NOTES
}

\begin{abstract}
${ }^{1}$ Meier, Stephan and Sprenger, Charles. (2007). "Selection into Financial Literacy Programs: Evidence from a Field Study.” Federal Reserve Bank, Boston. http://www.bos.frb.org/economic/ppdp/2007/ppdp075.htm.
\end{abstract}

${ }^{2}$ Olsen, Anya and Whitman, Kevin. (2007). "Effective Retirement Savings Programs: Design Features and Financial Education.” Social Security Bulletin. 67(2). Page 53-72.

${ }^{3}$ Ibid.

${ }^{4}$ Johnson, Elizabeth and Sherraden, Margaret. (2007). "From Financial Literacy to Financial Capability among Youth.” Journal of Sociology and Social Welfare. 36(3). Page 119-146.

${ }^{5}$ Hart, Keith. (2007). "Money is Always Personal and Impersonal." Anthropology Today. 23(5). Page 12-16.

${ }^{6}$ Rotfeld, Herbet. (2008). "Financial Aliteracy.” Journal of Consumer Affairs. 42(2). Page 306-309.

${ }^{7}$ Dietsch, Peter. (2006). "Show Me the Money: The Case for Income Transparency.” Journal of Social Philosophy. 37(2). Page 197-213.

${ }^{8}$ Dirubbo, Nancy. (2008). “Could You Pass a Fiscal Fitness Test?” Nurse Practitioner. 33(1). Page 9.

${ }^{9}$ Garner, Alan. (2006). "Should the Decline in the Personal Saving Rate Be a Cause for Concern?" Economic Review. 91(2). Page 5-28.

${ }^{10}$ Sullivan, Teresa; Warren, Elizabeth; and Westbrook, Jay. (2006). "Less Stigma or More Financial Distress: An Empirical Analysis of the Extraordinary Increase in Bankruptcy Filings." Stanford Law Review. 59(2). Page 212256.

${ }^{11}$ Vogler, Carolyn; Lyonette, Clare and Wiggins, Richard. (2008). "Money, Power and Spending Decisions in Intimate Relationships.” Sociological Review. 56(1). Page 117-143.

${ }^{12}$ Marriott, Pru. (2007). “An Analysis of First Experience Students' Financial Awareness and Attitude to Debt in a Post-1992 UK University. Higher Education Quarterly. 61(4). Page 498-519.

${ }^{13}$ Adams, Troy and Moore, Monique. (2007). "High-Risk Health and Credit Behavior Among 18- to 25-Year-Old College Students." Journal of American College Health. 56(2). Page 101-108.

${ }^{14}$ Tanne, Janice. (2008). "Downward Trend in Dementia Linked to Better Education and Personal Wealth." British Medical Journal. 336(7642). Page 466-467.

${ }^{15}$ Duffy, Brian. (1995). "Retirement Modeling Software: An Effective Tool but, Without a Plan and Some Motivation, the Tool is Limited." Benefits Quarterly. $4^{\text {th }}$ Quarter. Page 12-14. 
${ }^{16}$ Stawski, Robert; Hershey, Douglas; and Jacobs-Lawson, Joy. (2007). "Goal Clarity and Financial Planning Activities as Determinants of Retirement Savings Contributions. International Journal of Aging and Human Development. 64(1). Page 13-32.

${ }^{17}$ Guidolin, Massimo. (2007). "The Decline in the U.S. Personal Saving Rate: Is It Real and Is It a Puzzle?" Federal Reserve Bank of St. Louis Review. 89(6). Page 491-514.

${ }^{18}$ Dulebohn, James. (2007). "Retirement Savings Behavior of Higher Education Employees." Research in Higher Education. 48(5). Page 545-582.

${ }^{19}$ Ibid.

${ }^{20}$ Gonyea, Judith. (2007). "Improving the Retirement Prospects of Lower-Wage Workers in a DefinedContribution World." Families in Society. 88(3). Page 453-462.

${ }^{21}$ Davis, Carol. (2007). “Manage Your Pension Pot.” Nursing Standard. 22(11). Page 63.

${ }^{22}$ Rappaport, Anna. (2007). "Improving the Financial Status of Elderly Women: Issues in Savings, Pension Plans and Social Security. 23(1). Page 34-45.

${ }^{23}$ Chahen, Jill. (2007). "Heading Into the Home Stretch.” ABA Journal. 93(10). Page 56-57. 